\title{
Jurist-Diction
}

Volume 2 No. 6, November 2019

Histori artikel: Submit 2 September 2019; Diterima 2 Oktober 2019; Diterbitkan online 1 November 2019.

\section{Kepastian Hukum Sertipikat Hak Milik Masyarakat Hukum Adat Tengger}

\author{
Diyan Ricky Warisle dan Agus Sekarmadji \\ diyan.ricky.warisle-2015@fh.unair.ac.id \\ Universitas Airlangga
}

\begin{abstract}
Article $18 B$ paragraph (2) of the Indonesian Constitution of 1945 recognizes the existence of customary law communities along with their traditional rights. In 2015, the Tengger customary law community in Ngadisari village, Sukapura sub-district, Probolinggo district received a certificate of ownership which accommodated the local wisdom of the Tengger customary law community which had been taught to protect the land they owned by not selling it to outsiders. Based on the Ngadisari Village Regulation Number 2 of 2015 concerning the Rules of Land Arrangement in Ngadisari Village the land in Ngadisari village may not be sold or rented to outside parties or between residents without the recommendation of the Village Head and Customary Chairperson. This research was conducted with the aim of finding out the legal certainty of a certificate of ownership which accommodates the local wisdom of the Tengger customary law community. This research uses a statute approach, conceptual approach, and case study. The result of this research is that the certificate of ownership which accommodates the local wisdom of Tengger customary law community is in accordance with the rules of national land law so that it has the same validity as the certificate of ownership in general.
\end{abstract}

Keywords: Certificate; Local Wisdom; Tengger Customary Law Community; National Land Law.

\begin{abstract}
Abstrak
Pasal 18B ayat (2) Undang-Undang Dasar Negara Republik Indonesia Tahun 1945 mengakui keberadaan masyarakat hukum adat beserta hak tradisional yang dimilikinya. Pada tahun 2015, masyarakat hukum adat Tengger di desa Ngadisari, kecamatan Sukapura, kabupaten Probolinggo menerima sertipikat hak milik yang mengakomodir kearifan lokal masyarakat hukum adat Tengger terkait dengan melindungi tanah yang diimilikinya dengan tidak menjualnya kepada pihak luar. Berdasarkan Peraturan Desa Ngadisari Nomor 2 Tahun 2015 Tentang Tata Tertib Pengaturan Tanah di Desa Ngadisari tanah di desa Ngadisari tidak boleh dijual atau disewakan kepada pihak luar atau antar warga tanpa rekomendasi Kepala Desa dan Ketua Adat. Penelitian ini dilakukan dengan tujuan untuk mengetahui kepastian hukum dari sertipikat hak milik yang mengakomodir kearifan lokal yang dimiliki oleh masyarakat hukum adat Tengger. Penelitian ini menggunakan pendekatan perundangundangan, konseptual, dan studi kasus. Kesimpulan yang didapat yaitu bahwa sertipikat hak milik yang mengakomodir kearifan lokal tersebut sesuai dengan aturan hukum pertanahan nasional sehingga memiliki keberlakuan yang sama sebagaimana sertipikat hak milik pada umumnya.
\end{abstract}

Kata Kunci: Sertipikat; Kearifan Lokal; Masyarakat Hukum Adat Tengger; Hukum Tanah Nasional.

\section{Pendahuluan}

Berdasarkan Pasal 18B ayat (2) Undang-Undang Dasar Negara Republik Indonesia Tahun 1945 (UUD NRI Tahun 1945) keberadaan masyarakat hukum adat beserta dengan hak tradisional yang dimilikinya diakui oleh negara sepanjang 
masih hidup dan sesuai dengan perkembangan masyarakat dan prinsip NKRI. Dalam hukum tanah adat dikenal adanya hak persekutuan atas tanah yang dikenal sebagai hak purba, hak ulayat atau hak pertuanan dan hak perseorangan atas tanah. Hubungan antara hak persekutuan atas tanah dan hak perseorangan atas tanah yaitu saling mempengaruhi dalam hubungan yang mengempis dan mengembang, saling mendesak dan saling membatasi tanpa henti. ${ }^{1}$ Maksudnya yakni bahwa apabila hak persekutuan menguat, maka hak perseorangan akan melemah dan begitu pula sebaliknya. ${ }^{2}$ Melemahnya hak persekutuan dapat terlihat pada transaksi tanah pertanian berupa jual gadai, jual lepas, ataupun transaksi tanah lainnya dan terhadap pengerjaan tanah pertanian yang terus menerus oleh penduduk. Hak persekutuan akan menguat apabila terjadi pencabutan hak tanpa kerugian yang terjadi apabila tanah ditinggalkan, warga desa yang memiliki tanah berpindah ke tempat lain ataupun pada pemilik tanah yang meninggal dengan tanpa ahli waris. ${ }^{3}$

Masyarakat hukum adat Tengger merupakan masyarakat adat yang mendiami desa-desa di dataran tinggi yang membentang di kawasan Taman Nasional BromoTengger-Semeru yang terletak di kabupaten Malang, Pasuruan, Probolinggo, dan Lumajang. ${ }^{4}$ Salah satu desa yang didiami oleh masyarakat hukum adat Tengger yakni desa Ngadisari, kecamatan Sukapura, kabupaten Probolinggo, provinsi Jawa Timur. Aturan adat masyarakat hukum adat Tengger di bidang pertanahan mengatur mengenai larangan atau pantangan terhadap penjualan tanah kepada pihak di luar masyarakat hukum adat Tengger, dan apabila masyarakat hukum adat terpaksa menjual tanah yang dimilikinya maka penjualan atas tanah tersebut diutamakan untuk dilakukan dengan keluarga/kerabat dekat yakni warga desa yang berada di dusun yang sama. ${ }^{5}$

\footnotetext{
1 Iman Sudiyat, Hukum Adat Sketsa Asas (Liberty 1981).[3].

ibid.

3 ibid.[8].

4 Purnawan D. Negara, 'Hak Atas Tanah pada Masyarakat Tengger: Sebuah Refleksi atas Pelaksanaan Pengakuan “Hak Komunal atas Tanah” pada Masyarakat Tengger', (2016), 6 Digest Epistema.[27].

5 Kementerian Hukum dan Hak Asasi Manusia Republik Indonesia Badan Pembinaan Hukum Nasional, 'Laporan Akhir Tim Pemantauan dan Inventarisasi Perkembangan Hukum Adat Badan Pembinaan Hukum Nasional'.(2011).[102].
} 
Pada 9 Juli 2015, sebanyak 180 (seratus delapan puluh) sertipikat diserahkan kepada warga masyarakat adat kearifan lokal suku Tengger di desa Ngadisari, kecamatan Sukapura, kabupaten Probolinggo oleh Menteri ATR/BPN. ${ }^{6}$ Penyerahan sertipikat kepada masyarakat hukum adat Tengger disebut sebagai bentuk komitmen dalam memberikan perlindungan terhadap masyarakat adat serta sebagai langkah preventif untuk mencegah terjadinya sengketa pertanahan. ${ }^{7}$ Sertipikat yang diserahkan kepada masyarakat hukum adat Tengger tersebut merupakan sertipikat yang mengakomodir kearifan lokal masyarakat hukum adat Tengger yang ditandai dengan dicantumkannya stempel khusus berwarna merah pada halaman perubahan hak yang bertuliskan "Berdasarkan Peraturan Desa Ngadisari Kec. Sukapura No. 02 Tahun 2015 Tgl. 04 Mei 2015, Menyatakan Bahwa Tanah Ini Tidak Boleh Dijual Atau Disewakan Dengan Pihak Luar Atau Antar Warga Tanpa Rekomendasi Kepala Desa Dan Ketua Adat". ${ }^{8}$ Melalui keberadaan stempel merah tersebut dapat diketahui bahwa peralihan hak atas tanah terhadap tanah di desa Ngadisari hanya dapat dilakukan oleh antar masyarakat hukum adat Tengger atas rekomendasi dari Kepala Desa dan Ketua Adat. Oleh karena itu, sertipikat hak milik berstempel merah yang dimiliki masyarakat hukum adat Tengger atau sertipikat hak milik yang mengakomodir kearifan lokal tersebut oleh masyarakat setempat dikenal sebagai sertipikat kearifan lokal.

Hal mengenai sertipikat hak milik yang mengakomodir kearifan lokal masyarakat hukum adat Tengger menjadi menarik untuk dibahas mengingat terdapat suatu kekhususan berupa stempel merah pada halaman perubahan hak dalam sertipikat tersebut. Beranjak dari sertipikat hak milik yang mengakomodir kearifan lokal tersebut kemudian dapat dibahas mengenai hukum adat masyarakat adat Tengger di bidang pertanahan, jenis sertipikat hak atas tanah yang diterbitkan,

6 Julius Sembiring, Dinamika Pengaturan dan Permasalahan Tanah Ulayat (STPN Press 2018).[166-167].

7 Anon, 'Menteri Agraria/Kepala BPN Serahkan Sertipikat Tanah Kepada Masyarakat Hukum Adat Tengger', (Berita Kementerian Agraria dan Tata Ruang/Badan Pertanahan Nasional 2015) $<$ https://www.atrbpn.go.id/Berita/Siaran-Pers/menteri-agrariakepala-bpn-serahkan-sertipikat-tanah-kepada-masyarakat-adat-Tengger-59156>, diakses pada 21 November 2018.

8 Julius Sembiring, Loc.Cit. 
serta mengenai sesuai tidaknya sertipikat hak milik yang mengakomodir kearifan lokal masyarakat hukum adat Tengger dengan aturan Hukum Pertanahan Nasional.

\section{Hukum Adat Masyarakat Adat Tengger di Bidang Pertanahan}

Masyarakat hukum adat Tengger merupakan masyarakat yang tinggal di kawasan sekitar Gunung Bromo yang terletak di kabupaten Malang, Pasuruan, Probolinggo, dan Lumajang. Kediaman masyarakat hukum adat Tengger merupakan dataran tinggi yang memisahkan Jawa Tengah dengan wilayah yang dikenal dengan "ujung timur". ${ }^{9}$ Wilayah keberadaan masyarakat hukum adat Tengger merupakan satu-satunya wilayah Jawa yang masih memiliki tradisi keagamaan Hindu yang masih kental dan masih tradisional.

Desa Ngadisari merupakan salah satu desa tertua yang terletak di dataran tinggi dengan ketinggian 1800 meter dari permukaan laut yang berada di kecamatan Sukapura, kabupaten Probolinggo, provinsi Jawa Timur. Berdasarkan rencana tata ruang wilayah kabupaten Probolinggo, masyarakat hukum adat Tengger termasuk ke dalam kawasan lindung spiritual dan kearifan lokal ${ }^{10}$ serta merupakan kawasan strategis kepentingan sosial budaya. ${ }^{11}$ Secara administratif batas-batas desa Ngadisari adalah sebagai berikut, sebelah utara berbatasan dengan kabupaten Pasuruan; sebelah selatan berbatasan dengan kabupaten Lumajang; sebelah barat berbatasan dengan kabupaten Malang; dan sebelah timur berbatasan dengan desa Wonotoro.

Tengger merupakan singkatan kata "Teng" yang berasal dari kata Anteng dan "Ger" yang berasal dari kata Seger dengan berdasarkan pada legenda Rara Anteng dan Jaka Seger. Legenda tersebut menceritakan mengenai Rara Anteng dan Jaka Seger, sepasang suami istri yang memiliki 25 anak namun harus mengorbankan

\footnotetext{
9 Kementerian Hukum dan Hak Asasi Manusia Republik Indonesia Badan Pembinaan Hukum Nasional, Op.Cit.[105].

${ }^{10}$ Pasal 26 ayat (6) Peraturan Daerah Kabupaten Probolinggo Nomor 23 Tahun 2011 Tentang Rencana Tata Ruang Wilayah Kabupaten Probolingo Tahun 2010-2029.

${ }^{11}$ Pasal 44 ayat (1) Peraturan Daerah Kabupaten Probolinggo Nomor 23 Tahun 2011 Tentang Rencana Tata Ruang Wilayah Kabupaten Probolingo Tahun 2010-2029.
} 
salah satu anaknya dengan menjerumuskannya ke dalam kawah gunung Bromo untuk menyelamatkan saudara-saudaranya. ${ }^{12}$

Ciri utama yang dimiliki oleh masyarakat hukum adat Tengger yaitu rakyat yang patuh pada pimpinan (sabda pandhita ratu) dan taat melaksanakan tradisi seperti selamatan perayaan hari besar dan upacara adat. ${ }^{13}$ Kontak sosial masyarakat hukum adat Tengger masih bersifat tradisional karena masih adanya alam pikiran yang magis-animistis, adanya ikatan individu yang masih kuat, serta terdapat larangan dan kewajiban yang membawa konsekuensi dalam kehidupan seharihari. Pergaulan antar warga masyarakat hukum adat Tengger bersifat komunal karena hubungan batin diantaranya masih sangat kuat dan masyarakat hukum adat Tengger memiliki sikap saling menghargai dan tolong menolong satu sama lain. Budaya gotong royong masyarakat hukum adat Tengger di desa Ngadisari disebut dengan "Sayan". ${ }^{14}$ Budaya sayan tersebut dapat berbentuk memberikan bantuan mendirikan rumah atau menaikkan atap dan genting, bantuan dalam mengurus hajatan, bantuan dalam mengatasi bencana alam, ataupun bantuan dalam kegiatan bercocok tanam seperti pada masa panen. Selain itu masyarakat hukum adat Tengger di desa Ngadisari percaya akan adanya hukum karma atau hukum sebab-akibat yang berlandaskan pada welas asih pepitu (cinta kasih yang tujuh) sehingga mereka saling berbuat baik, tidak menyakiti, dan apabila terjadi suatu masalah maka akan diselesaikan secara musyawarah. ${ }^{15}$

Hubungan antara masyarakat hukum adat Tengger dengan tanahnya sangat erat kaitannya dengan keinginannya untuk berbakti kepada leluhurnya dengan cara merawat dan mengolah tanah yang ada agar dapat dilakukan sesembahan pada saat bulan Kasada tiba. Masyarakat hukum adat Tengger memiliki prinsip hidup untuk ngayomi, ngayani, dan ngayemi keluarga sehingga mereka diwajibkan untuk

${ }_{12}$ J.Nicolaas Warouw, et.al., Inventarisasi Komunitas Adat Tengger Desa Ngadisari Kecamatan Sukapura Kabupaten Probolinggo Jawa Timur (Balai Pelestarian Nilai Budaya 2012).[13].

13 ibid.

${ }^{14}$ Harry Waluyo, Sistem Pemerintahan Tradisional di Tengger Jawa Timur (Departemen Pendidikan dan Kebudayaan 1997).[44].

15 ibid. [25-26]. 
ngemong (memelihara tanah) terhadap tanah yang dimilikinya. Maksudnya adalah bahwa tanah tersebut harus diolah dan dimanfaatkan sebagai sumber kehidupan bagi kehidupan dirinya dan keluarganya. ${ }^{16}$ Bagi masyarakat hukum adat Tengger tanah merupakan induk kehidupan bagi setiap makhluk, tidak adanya tanah menyebabkan putusnya rantai kehidupan bagi masyarakat hukum adat Tengger. Oleh karenanya masyarakat hukum adat Tengger memperlakukan tanahnya dengan sangat hati-hati untuk menjaga keberlanjutan fungsinya. ${ }^{17}$

Masyarakat hukum adat Tengger mengenal suatu kepemilikan tanah kolektif yang disebut dengan "tempat kerukunan" namun dalam perkembangannya tanah tersebut dibagi-bagikan kepada individu-individu yang merupakan penduduk asli Tengger yang kemudian kepemilikan tanah kolektif tersebut berubah statusnya menjadi kepemilikan pribadi yang dikenal sebagai tanah yasan. ${ }^{18}$ Berdasarkan aturan adat yang diajarkan oleh leluhur, tanah yang dimiliki oleh masyarakat hukum adat Tengger dilarang untuk dijual kepada pihak luar agar tanah tersebut tetap terlindungi dan nantinya hanya diperuntukkan untuk generasi penerus masyarakat hukum adat Tengger tersebut ${ }^{19}$ sehingga tanah tersebut hanya dapat diwariskan secara turun temurun pada generasi berikutnya ataupun kepada penduduk asli Tengger yang berada di dusun yang sama. Tanah tersebut hanya dapat dijual kepada kerabat dekat atau sesama warga desa dan dusun yang sama apabila terpaksa harus menjualnya. ${ }^{20}$ Hal tersebut menandakan bahwa tanah yang ada di kawasan Tengger hanya dapat dikuasai oleh masyarakat hukum adat Tengger itu sendiri dan tidak dikuasai oleh orang luar masyarakat hukum adat Tengger atau pendatang. ${ }^{21}$

\footnotetext{
16 Purnawan D. Negara, Op.Cit.[28].

${ }^{17}$ Kementerian Hukum dan Hak Asasi Manusia Republik Indonesia Badan Pembinaan Hukum Nasional, Op.Cit.[103].

18 ibid.

19 J. Nicolaas Warouw, et.al., Op.Cit.[23].

${ }^{20}$ Kementerian Hukum dan Hak Asasi Manusia Republik Indonesia Badan Pembinaan Hukum Nasional, Op.Cit.[102].

${ }^{21}$ ibid.[h.94].
} 


\section{Karakteristik Sertipikat Hak Milik}

Hak atas tanah berupa hak milik disebutkan dalam Pasal 16 ayat(1)Undang-Undang Nomor 5 Tahun 1960 (UUPA) yang kemudian diatur lebih lanjut dalam Pasal 20 hingga Pasal 27 UUPA. Dalam Pasal 20 UUPA menyebutkan bahwa hak milik adalah hak yang turun-termurun, terkuat, dan terpenuh. Hak milik sebagai hak yang turun temurun artinya bahwa hak milik berlangsung terus menerus selama pemegang hak masih hidup dan apabila pemegang hak milik telah meninggal maka dapat dilanjutkan oleh ahli warisnya yang sah dan memenuhi syarat subyek hak milik.22 Selanjutnya hak milik sebagai hak yang terkuat artinya adalah hak milik memiliki kedudukan yang lebih tinggi daripada hak atas tanah lainnya karena hak milik tidak memiliki batasan waktu tertentu, mudah dipertahankan dari gangguan orang lain, serta tidak mudah hapus. Sedangkan hak milik sebagai hak terpenuh artinya bahwa pemegang hak milik berwenang untuk menggunakan tanahnya lebih luas dibandingkan dengan hak atas tanah lainnya dan dapat menjadi induk dari hak atas tanah lainnya. Lebih lanjut dalam pasal yang sama disebutkan bahwa hak milik dapat beralih yaitu perpindahan hak milik yang terjadi melalui peristiwa hukum dan dialihkan yaitu perpindahan hak milik yang terjadi melalui perbuatan hukum.

Berdasarkan Pasal 21 UUPA yang menjadi subyek hak milik hanyalah Warga Negara Indonesia dan badan hukum yang dapat mempunya hak milik dan syaratsyaratnya ditetapkan oleh pemerintah. Apabila orang asing atau orang dengan warga kenegaraan ganda memperoleh hak milik melalui pewarisan tanpa wasiat atau pencampuran harta karena perkawinan, maka ia harus melepaskan hak milik yang didapatnya dalam jangka waktu 1 (satu) tahun.

Hak milik dapat terjadi menurut hukum adat, terjadi karena penetapan pemerintah, dan terjadi karena ketentuan undang-undang sebagaimana diatur dalam Pasal 22 UUPA. Terjadinya hak milik menurut hukum adat berkaitan hubungan antara hak perseorangan atas tanah dan hak ulayat yang mengempis dan mengembang, perolehan hak milik oleh masyarakat adat dapat dilihat melalui cara masyarakat adat memperoleh tanahnya yaitu dengan cara membuka hutan dan

\footnotetext{
${ }^{22}$ Penjelasan Pasal 20 Undang-Undang Nomor 5 Tahun 1960 Tentang Pokok-Pokok Agraria.
} 
mengusahakannya sendiri, pembukaan tanah atau karena timbulnya lidah tanah (Aanslibbing). Terjadinya hak milik karena penetapan pemerintah berkaitan dengan asal mula tanah yang berasal dari tanah negara yang diperoleh melalui pendaftaran Surat Keputusan Pemberian Hak (SKPH) yang dilakukan oleh pemohon. Sedangkan terjadinya hak milik karena ketentuan undang-undang yaitu kaitannya dengan hak atas tanah yang diciptakan oleh undang-undang yang diatur dalam Pasal I, Pasal II, dan Pasal VII ayat (1) Ketentuan-Ketentuan Konversi menurut UUPA.

Berdasarkan Pasal 25 UUPA hak milik dapat dijadikan sebagai jaminan utang dengan dibebani dengan hak tanggungan. Pembebanan hak tanggungan dapat dilakukan setelah memenuhi unsur-unsur yang harus terpenuhi secara kumulatif berupa adanya perjanjian utang piutang sebagai perjanjian pokok; Adanya Akta Pemberian Hak Tanggungan sebagai perjanjian ikutan/tambahan; dan Adanya Pendaftaran Akta Pemberian Hak Tanggungan (APHT). ${ }^{23}$

Hapusnya hak milik mengakibatkan tanah tersebut jatuh kepada negara dan menjadi tanah negara. Berdasarkan Pasal 27 UUPA faktor-faktor yang menyebabkan hapusnya hak milik diantaranya:

1.) karena pencabutan hak berdasarkan Pasal 18;

2.) karena penyerahan dengan sukarela oleh pemiliknya;

3.) karena ditelantarkan;

4.) karena subyek haknya tidak memenuhi syarat sebagai subyek hak milik atas tanah;

5.) karena peralihan hak yang mengakibatkan tanahnya berpindah kepada pihak lain tidak memenuhi syarat sebagai subyek hak milik atas tanah; dan

6.) karena tanahnya musnah.

Oleh karenanya, pemegang hak milik selain dapat menggunakan atau menggarap atau mengerjakan sendiri tanah yang dimilikinya, pemegang hak milik dapat pula melakukan suatu perbuatan hukum berupa menjual, menggadaikan, menyewakan, mewakafkan, menghibahkan, dan/atau menjadikannya sebagai jaminan hutang berupa pembebanan hak tanggungan terhadap tanah yang dimilikinya. ${ }^{24}$

${ }^{23}$ Urip Santoso, Hukum Agraria: Kajian Komprehensif (Kencana 2012).[100]. selanjutnya disebut Urip Santoso I

24 Ilyas Ismail, Kajian Terhadap Hak Milik Atas Tanah Yang Terjadi Berdasarkan Hukum Adat (2012) 56 Kanun Jurnal Ilmu Hukum. [6]. 


\section{Penerbitan Sertipikat Hak Milik}

Berdasarkan Pasal 1 angka 1 Peraturan Pemerintah Nomor 24 Tahun 1997 (PP Nomor 24 Tahun 1997) kegiatan pendaftaran tanah didefinisikan sebagai kegiatan yang dilakukan oleh pemerintah secara terus-menerus, berkesinambungan dan teratur, yang meliputi pengumpulan, pengolahan, pembukuan dan penyajian serta pemeliharaan data fisik dan data yuridis, dalam bentuk peta dan daftar, mengenai bidang-bidang tanah dan satuan rumah susun, termasuk pemberian surat tanda bukti hak bagi bidang-bidang tanah yang sudah ada haknya dan hak milik atas satuan rumah susun serta hak-hak tertentu yang membebaninya. Sejalan dengan tujuan pendaftaran yang diatur dalam Pasal 19 ayat (1) UUPA jo. Pasal 3 PP Nomor 24 Tahun 1997 menyebutkan bahwa tujuan dari pendaftaran tanah adalah untuk menjamin kepastian hukum (rechtscadaster), memberikan perlindungan hukum kepada pemegang hak atas tanah, serta untuk mewujudkan tertib administrasi, maka segala hak atas tanah yang dimiliki oleh warga Indonesia wajib didaftarkan pada Badan Pertanahan Nasional (BPN).

Berdasarkan Pasal 11 PP Nomor 24 Tahun 1997 pelaksanaan pendaftaran tanah terdiri dari pendaftaran tanah untuk pertama kali dan pemeliharaan data pendaftaran tanah. Pendaftaran tanah untuk pertama kali merupakan kegiatan pendaftaran tanah yang dilakukan terhadap tanah yang belum pernah didaftarkan sebelumnya yang kemudian akan diterbitkan sertipikat terhadap tanah yang baru didaftarkan tersebut. Pendaftaran tanah untuk pertama kali dapat dilaksanakan melalui kegiatan pendaftaran tanah secara sporadik dan pendaftaran tanah secara sistematis yang membedakan diantara keduanya, yaitu pelaksanaan pendaftaran tanah secara sporadik berdasarkan atas permintaan pihak yang berkepentingan sedangkan pendaftaran tanah secara sistematis berdasarkan atas rencana kerja dan wilayah tertentu yang ditetapkan oleh Menteri Agraria dan Tata Ruang/Kepala Badan Pertanahan Nasional.

Pemeliharaan data pendaftaran tanah merupakan pendaftaran yang dilakukan pada saat terjadi perubahan-perubahan terhadap tanah yang telah terdaftar yang ditandai dengan diperlukannya penyesuaian terhadap perubahan 
yang terjadi terhadap data yuridis dan data fisik tanah tersebut. Perubahan yang dimaksud dapat berupa berubahnya nama pemilik hak atas tanah karena telah terjadi peralihan hak terhadap tanah tersebut, hapusnya pembebanan atas tanah, hapusnya atau diperpanjangnya jangka waktu hak atas tanah, dapat pula karena terhadap tanah tersebut dilakukan pemecahan, penggabungan, atau pemisahan. Pemeliharaan data pendaftaran tanah perlu dilakukan agar data yang terdapat pada kantor pertanahan merupakan data yang sesuai dengan keadaan yang mutakhir atau yang terbaru, sehingga masyarakat dapat memperoleh data yang benar setiap saat.

Diterbitkannya sertipikat sebagai alat pembuktian yang kuat akan memberikan kepastian hukum kepada pemegang haknya sebab dalam sertifikat tersebut mencantumkan data yuridis dan data fisik tanah yang dianggap benar sepanjang tidak ada yang membuktikan sebaliknya dengan alat bukti lain berupa sertipikat, petuk pajak bumi, ataupun kutipan Letter C. ${ }^{25}$ Data fisik merupakan keterangan mengenai lokasi, batas-batas, luas bangunan beserta dengan tanaman yang berada diatasnya yang diperoleh melalui proses pengukuran dan pemetaan atas bidang tanah, dan penetapan batas atas bidang tanah. ${ }^{26}$ Data yuridis merupakan keterangan mengenai status hukum atas tanah berupa jenis hak, subyek hak, ada tidaknya hak pihak lain, serta beban-beban yang membebani tanah tersebut. ${ }^{27}$ Pasal 23 dan Pasal 24 PP Nomor 24 Tahun 1997 mengatur mengenai cara pembuktian hak-hak lama dan hak-hak baru untuk memperoleh kebenaran data yuridis.

Melalui Pasal 19 ayat (2) huruf c UUPA, Pasal 1 angka 20 PP Nomor 24 Tahun 1997, dan Pasal 9 PP Nomor 24 Tahun 1997 dapat diketahui bahwa sertifikat diterbitkan sesuai dengan jenis hak yang didaftarkan, sehingga macam-macam sertipikat berdasarkan obyek pendaftaran tanah diantaranya, dapat berupa: ${ }^{28}$

\footnotetext{
${ }^{25}$ Urip Santoso, 'Penyimpangan Dalam Penerbitan Sertipikat Hak Atas Tanah', (2013), 18 Perspektif.[123] selanjutnya disebut Urip Santoso II

${ }^{26}$ Boedi Harsono, Hukum Agraria Indonesia Sejarah Pembentukan Undang-Undang Pokok Agraria, Isi Dan Pelaksanaannya Jilid I, (Djambatan 2003).[73].

27 ibid.

${ }^{28}$ Urip Santoso I. Op.Cit.[317].
} 

a. Sertipikat Hak Milik;
b. Sertipikat Hak Guna Usaha;
c. Sertipikat Hak Guna Bangunan atas tanah negara;
d. Sertipikat Hak Guna Bangunan atas tanah Hak Pengelolaan;
e. Sertipikat Hak Pakai atas tanah negara;
f. Sertipikat Hak Pakai atas tanah Hak Pengelolaan;
g. Sertipikat tanah Hak Pengelolaan;
h. Sertipikat tanah Wakaf;
i. Sertipikat Hak Milik Atas Satuan Rumah Susun;
j. Sertipikat Hak Milik Atas Satuan Non Rumah Susun;
k. Sertipikat Hak Tanggungan.

Sertipikat sebagai alat bukti yang kuat diterbitkan oleh Kantor Badan Pertanahan Nasional Kabupaten/Kota dan hanya diterbitkan untuk kepentingan pemegang hak ${ }^{29}$ dengan disesuaikan dengan data fisik dan data yuridis yang terdaftar dalam surat ukur dan buku tanah. Oleh karena itu, sertipikat hanya dapat diserahkan kepada pihak yang namanya tercantum dalam sertipikat yang telah diterbitkan tersebut selaku pemegang hak atas tanah atau kepada pihak lain yang mendapat kuasa untuk menerima sertipikat.

Berdasarkan Pasal 65 Peraturan Menteri Agraria/Kepala Badan Pertanahan Nasional Nomor 3 Tahun 1997 Tentang Ketentuan Pelaksanaan Peraturan Pemerintah Nomor 24 Tahun 1997 Tentang Pendaftaran Tanah (selanjutnya disebut Permen Agraria Nomor 3 Tahun 1997) terdapat 3 (tiga) asal pemberian hak, diantaranya:

1. Penegasan konversi

Diberikan terhadap hak atas bidang tanah yang memiliki alat bukti tertulis lengkap dan terhadap hak atas bidang tanah yang tidak memiliki alat bukti tertulis tidak lengkap tetapi ada keterangan saksi maupun pernyataan yang bersangkutan. Berdasarkan Pasal 60 ayat (1) dan ayat (2) Permen Agraria 3 Tahun 1997 alat bukti tertulis tersebut berlaku untuk pembuktian hak lama dan hak baru.

2. Pengakuan Hak

Diberikan terhadap hak atas bidang tanah kepemilikannya dibuktikan dengan

${ }^{29}$ Pasal 31 Peraturan Pemerintah Nomor 24 Tahun 1997 Tentang Pendaftaran Tanah. 
melalui penguasaan secara fisik selama 20 (dua puluh) tahun secara berturutturut karena tidak memiliki alat bukti kepemilikan yang diatur dalam Pasal 60 ayat (2) Permen Agraria Nomor 3 Tahun 1997.

3. Pemberian Hak

Diberikan terhadap tanah-tanah negara termasuk tanah negara yang merupakan obyek landreform.

Berdasarkan penjelasan tersebut dapat diketahui bahwa hak milik dapat berasal dari penegasan konversi apabila memiliki bukti yang lengkap atau apabila bukti tidak lengkap, maka dilengkapi dengan keterangan saksi dan pihak yang bersangkutan. Hak milik juga dapat berasal dari pengakuan hak yang dibuktikan dengan melalui penguasaan fisik atas tanah selama 20 (dua puluh) tahun secara berturut-turut karena pemilik tidak memiliki alat bukti. Selain itu, hak milik berasal dari pemberian hak apabila tanah berasal dari tanah negara.

\section{Sertipikat Hak Milik Masyarakat Hukum Adat Tengger}

Tanah yang dimiliki oleh masyarakat hukum adat Tengger sebagian besar diperoleh dengan melalui pewarisan mengingat masyarakat hukum adat Tengger diajarkan untuk tidak menjual tanahnya kepada pihak luar, sehingga apabila pemilik tanah tersebut meninggal dunia maka tanah tersebut selanjutnya diwariskan secara turun-temurun kepada penerusnya. Pemilik tanah memiliki wewenang untuk memanfaatkan dan/atau menggunakan tanah yang dimilikinya dengan seluas-luasnya untuk kepentingan pertanian, perkebunan, ataupun mendirikan bangunan dengan syarat bahwa dalam memanfaatkan dan/atau menggunakan tanahnya tersebut tetap memerhatikan fungsi sosial sebagaimana diatur dalam Pasal 6 UUPA. Sebagaimana diatur dalam Pasal 20 ayat (1) UUPA, tanah yang dimiliki oleh masyarakat adat Tengger memiliki sifat Hak Milik yaitu turun-temurun, terkuat, dan terpenuh.

Masyarakat hukum adat Tengger diajarkan untuk menjaga tanah yang dimilikinya dengan tidak menjual tanah tersebut kepada pihak luar, sehingga berdasarkan pada ajaran adat tersebut pemilik tanah di desa Ngadisari hanya dibatasi 
pada masyarakat asli desa Ngadisari. Berdasarkan pada wawancara dengan Kepala Desa Ngadisari pada 11 Desember 2018, masyarakat asli desa Ngadisari adalah orang-orang yang pusat kehidupannya berada di desa Ngadisari, artinya bahwa orang tersebut lahir, hidup, tinggal, dan menetap di desa Ngadisari. Meskipun terdapat pembatasan berupa perseorangan dengan identitas asli yang berasal dari desa Ngadisari, namun pembatasan tersebut tidak bertentangan dengan syarat subyek Hak Milik yang diatur dalam Pasal 21 ayat (1) UUPA mengingat masyarakat di desa Ngadisari pada umumnya berkewarganegaraan Indonesia. Selain itu, hal tersebut juga tidak bertentangan dengan larangan kepemilikan tanah absentee atau tanah guntai yang mewajibkan tanah dan pemiliknya berada dalam kecamatan yang sama sebagaimana diatur dalam Pasal 17 UUPA jo. Peraturan Pengganti Undang-Undang Nomor 56 Tahun 1960 Tentang Penetapan Luas Tanah Pertanian jo. Peraturan Menteri Agraria dan Tata Ruang/Kepala Badan Pertanahan Nasional Nomor 18 Tahun 2016 Tentang Pengendalian Penguasaan Tanah Pertanian karena lingkup desa yang lebih kecil daripada kecamatan sehingga tanah di desa Ngadisari dapat dimanfaatkan secara aktif oleh masyarakat desa Ngadisari itu sendiri. Selain itu, pada halaman perubahan sertipikat hak milik tanah pertanian obyek landreform juga terdapat stempel serupa yang pada intinya menyatakan bahwa pemilik tanah pertanian hanya dapat memindah tangankan tanah yang dimilikinya setelah memperolah izin dari Kantor BPN Kabupaten/Kota setempat.

Terkait dengan peralihan hak sebagaimana stempel merah yang terdapat pada halaman perubahan, tanah yang terdapat di desa Ngadisari pada dasarnya hanya dapat beralih melalui pewarisan dan tidak dapat dialihkan kepada pihak luar. Namun tidak menutup kemungkinan tanah tersebut dapat dialihkan melalui jual-beli dengan syarat pembeli tanah masih merupakan masyarakat adat Tengger di desa Ngadisari dan diperlukannya rekomendasi dari Kepala Desa dan Kepala Adat. Sebagaimana diatur dalam Pasal 20 ayat (2) UUPA, tanah yang terdapat di desa Ngadisari dapat beralih dan dapat dialihkan namun dengan syarat berupa diperlukannya rekomendasi oleh Kepala Desa dan Kepala Adat apabila tanah tersebut akan dialihkan melalui jual-beli kepada pihak luar atau antar warga. 
Berkenaan dengan asal hak atau terjadinya Hak Milik yang diatur dalam Pasal 22 UUPA dapat diketahui bahwa tanah yang terdapat di desa Ngadisari merupakan tanah yang terjadi menurut ketentuan hukum adat. Sebagaimana penjabaran Kepala Desa Ngadisari pada 11 Desember 2018 yang juga menyebutkan bahwa tanah di desa Ngadisari merupakan tanah yasan, yaitu tanah hak milik yang dikenal dalam istilah hukum adat. Selain itu, berdasarkan pada "Laporan Akhir Tim Pemantauan Dan Inventarisasi Perkembangan Hukum Adat Badan Pembinaan Hukum Nasional" yang ditulis oleh Noor M. Aziz dapat diketahui bahwa tanah tersebut pada mulanya berasal dari tanah kolektif yang disebut "tempat kerukunan" yang telah dibagibagikan kepada penduduk asli Tengger secara individu. ${ }^{30}$ Berdasarkan hubungan antara hak persekutan atas tanah dan hak perseorangan atas tanah yang mengempis dan mengembang dapat diketahui bahwa dengan dibagi-bagikannya tanah kolektif tersebut kepada individu penduduk asli Tengger menyebabkan hak perseorangan terhadap tanah tersebut semakin kuat sedangkan hak kolektif terhadap "tempat kerukunan" tersebut semakin lemah dan menghilang. Di sisi lain, terjadinya Hak Milik terhadap tanah yang terdapat di desa Ngadisari juga dapat dikarenakan oleh ketentuan undang-undang yang berkaitan dengan Ketentuan-Ketentuan Konversi Menurut UUPA dan Peraturan Menteri Pertanian dan Agraria Nomor 2 Tahun 1962 Tentang Penegasan dan Pendaftaran Bekas Hak-Hak Indonesia Atas Tanah yang salah satunya mengatur mengenai hak yasan yang dapat dikonversi menjadi hak milik jika memenuhi syarat sebagai subyek Hak Milik. Penegasan konversi hak yasan menjadi hak milik baru dapat diperoleh apabila pemilik tanah dapat membuktikan kepemilikannya atas tanah tersebut dengan tanda bukti hak berupa petuk pajak bumi/landrente, girik, kekitir, pipil, Verponding Indonesia, IPEDA, IREDA, atau kutipan Letter C sebagaimana diatur dalam Pasal 23 dan Pasal 24 PP Nomor 24 Tahun 1997.

Terkait dengan pembebanan hak tanggungan yang diatur dalam Pasal 25 UUPA, tanah yang terdapat di desa Ngadisari juga dapat dibebani dengan

\footnotetext{
${ }^{30}$ Kementerian Hukum dan Hak Asasi Manusia Republik Indonesia Badan Pembinaan Hukum Nasional, Loc.Cit.
} 
hak tanggungan. Namun terdapat unsur tambahan yang wajib dipenuhi selain keharusan akan adanya perjanjian utang piutang sebagai perjanjian pokok, APHT sebagai perjanjian tambahan, dan adanya pendaftaran terhadap akta pemberian hak tanggungan, unsur tambahan yang dimaksud yakni terkait dengan rekomendasi oleh Kepala Desa dan Ketua Adat.

Penerbitan sertipikat hak milik yang mengakomodir kearifan lokal masyarakat hukum adat Tengger di desa Ngadisari oleh BPN Kabupaten/Kota merupakan hasil dari proses pendaftaran tanah untuk pertama kali melalui PRONA ${ }^{31}$ sebagaimana diatur dalam Peraturan Menteri Agraria dan Tata Ruang/Kepala Badan Pertanahan Nasional Nomor 1 Tahun 2015 Tentang Program Nasional (PRONA) (Permen ATR/BPN Nomor 1 Tahun 2015) dan PP Nomor 24 Tahun 1997. Dicantumkannya stempel merah pada halaman perubahan sertipikat kearifan lokal merupakan wujud pengakuan terhadap hukum adat Tengger di bidang pertanahan yang dilakukan oleh BPN Kabupaten/Kota dalam mengakomodir kearifan lokal ke dalam sertipikat. Sehingga, melalui keberadaan stempel merah dalam sertipikat hak milik yang mengakomodir kearifan lokal tersebut, maka pemilik tanah tidak dapat dengan mudah menjual atau menyewakan tanah yang dimilikinya kepada pihak luar karena untuk melakukan hal tersebut dibutuhkan rekomendasi yang dibuat oleh Kepala Desa dan Ketua Adat.

\section{Kesimpulan}

Sertipikat hak milik yang mengakomodir kearifan lokal yang dimiliki oleh masyarakat hukum adat Tengger di desa Ngadisari, kecamatan Sukapura, kabupaten Probolinggo telah sesuai dengan aturan Hukum Pertanahan Nasional. Oleh karenanya, sertipikat hak milik yang mengakomodir kearifan lokal tersebut berlaku sebagaimana sertipikat hak milik pada umumnya yang memiliki sifat turun-temurun, terkuat, dan terpenuh, dapat beralih dan dapat dialihkan, serta dapat dibebani hak tanggungan sebagaimana diatur dalam Pasal 20 hingga Pasal 27 UUPA. Keberadaan

\footnotetext{
${ }^{31}$ Purnawan D. Negara, Op.Cit.[30].
} 
stempel merah pada halaman perubahan sertipikat hak milik masyarakat hukum adat Tengger yang bertuliskan "Berdasarkan Peraturan Desa Ngadisari Kec. Sukapura No. 02 Tahun 2015 Tgl. 04 Mei 2015, Menyatakan Bahwa Tanah Ini Tidak Boleh Dijual Atau Disewakan Dengan Pihak Luar Atau Antar Warga Tanpa Rekomendasi Kepala Desa Dan Ketua Adat" merupakan bentuk pengakuan terhadap tradisi turun temurun masyarakat hukum adat Tengger di bidang pertanahan yang dilakukan oleh BPN Kabupaten/Kota Probolinggo sebagaimana dimandatkan dalam Pasal 18B ayat (2) UUD NRI Tahun 1945.

\section{Daftar Bacaan}

\section{Buku}

Boedi Harsono, Hukum Agraria Indonesia Sejarah Pembentukan Undang-Undang Pokok Agraria, Isi Dan Pelaksanaannya Jilid I (Djambatan 2003).

Harry Waluyo, Sistem Pemerintahan Tradisional di Tengger Jawa Timur (Departemen Pendidikan dan Kebudayaan 1997).

Iman Sudiyat, Hukum Adat Sketsa Asas (Liberty 1981).

J. Nicolaas Warouw, et.al., Inventarisasi Komunitas Adat Tengger Desa Ngadisari Kecamatan Sukapura Kabupaten Probolinggo Jawa Timur (Balai Pelestarian Nilai Budaya 2012).

Julius Sembiring, Dinamika Pengaturan dan Permasalahan Tanah Ulayat (STPN Press 2018).

Kementerian Hukum dan Hak Asasi Manusia Republik Indonesia Badan Pembinaan Hukum Nasional, Laporan Akhir Tim Pemantauan dan Inventarisasi Perkembangan Hukum Adat Badan Pembinaan Hukum Nasional (BPHN 2011).

Urip Santoso, Hukum Agraria: Kajian Komprehensif(Kencana 2012).

\section{Jurnal}

Ilyas Ismail, 'Kajian Terhadap Hak Milik Atas Tanah Yang Terjadi Berdasarkan Hukum Adat' (2012) Kanun Jurnal Ilmu Hukum 56.

Maria Cecilia Pricemarina, et.al., 'Pembatasan Hak Bagi Pemilik Sertifikat 
Hak Milik Atas Tanah Di Wilayah Adat Kebirangga Kecamatan Maukaro Kabupaten Ende (Studi Di Wilayah Adat Kebirangga Kecamatan Maukaro Kabupaten Ende) (2015) Arena Hukum 8.

Purnawan D. Negara, 'Hak Atas Tanah Pada Masyarakat Tengger: Sebuah Refleksi Atas Pelaksanaan Pengakuan "Hak Komunal Atas Tanah" Pada Masyarakat Tengger' (2016) Digest Epistema 6.

Urip Santoso, 'Penyimpangan Dalam Penerbitan Sertipikat Hak Atas Tanah' (2013) Perspektif 18.

\section{Laman}

<https://www.atrbpn.go.id/Berita/Siaran-Pers/menteri-agrariakepala-bpnserahkan-sertipikat-tanah-kepada-masyarakat-adat-Tengger-59156>

\section{Perundang-undangan}

Undang- Undang Dasar Negara Republik Indonesia Tahun 1945.

Undang-Undang Nomor 5 Tahun 1960 Tentang Pokok-Pokok Agraria, (Lembaran Negara Tahun 1960 Nomor 104, Tambahan Lembaran Negara Nomor 2043).

Peraturan Pemerintah Nomor 24 Tahun 1997 Tentang Pendaftaran Tanah, (Lembaran Negara Tahun 1997 Nomor 59, Tambahan Lembaran Negara Nomor 3696).

Peraturan Menteri Agraria/Kepala Badan Pertanahan Nasional Nomor 3 Tahun 1997 Tentang Ketentuan Pelaksanaan Peraturan Pemerintah Nomor 24 Tahun 1997 Tentang Pendaftaran Tanah.

Peraturan Menteri Agraria dan Tata Ruang/Kepala Badan Pertanahan Nasional Nomor 1 Tahun 2015 Tentang Program Nasional Agraria (PRONA) (Berita Negara Tahun 2015 Tahun 183).

Peraturan Daerah Kabupaten Probolinggo Nomor 3 Tahun 2011 Tentang Rencana Tata Ruang Wilayah Kabupaten Probolinggo Tahun 2010-2029.

HOW TO CITE: Diyan Ricky Warisle dan Agus Sekarmadji, 'Kepastian Hukum Sertipikat Hak Milik Masyarakat Hukum Adat Tengger' (2019) Vol. 2 No. 6 Jurist-Diction. 
--halaman ini sengaja dibiarkan kosong-- 